\title{
Management Systems and Good Practices Related to the Sustainable Supply Chain Management
}

\author{
Hong Yuh Ching ${ }^{1} \&$ Mayco Anderson Moreira ${ }^{2}$ \\ ${ }^{1}$ Business Department, Centro Universitário da FEI, São Bernardo do Campo, Brazil \\ ${ }^{2}$ Research Student, Centro Universitário da FEI, São Bernardo do Campo, Brazil \\ Correspondence: Hong Yuh Ching, Business Department, Centro Universitário da FEI, Av. Humberto de Alencar \\ Castelo Branco, 3972, 09850-901, São Bernardo do Campo, Brazil. Tel: 55-11-4353-2900. E-mail: \\ hongching@fei.edu.br
}

Received: March 20, 2014 Accepted: April 10, 2014 Online Published: May 27, 2014

doi:10.5539/jms.v4n2p34 URL: http://dx.doi.org/10.5539/jms.v4n2p34

\begin{abstract}
The objective of this paper is to identify the good practices and management systems related to Sustainable Supply Chain Management SSCM. This study is qualitative with exploratory objective. By examining SSCM publications across journals and across time (from 1997 to 2011) in the three aspects of sustainability, there is a growing number from 2004/2005 onwards. The social aspect is rarely addressed in the literature, in contrast with environmental followed by the economic. The management systems reflect this finding as well as with the eight practices identified. There is no management system that addresses social responsibility. Only two practices address the triple bottom line aspects, while four address environmental and economic aspects, one deals with social and economic and one deals with environmental aspect. The two frameworks proposed by the authors are the contribution in this paper. The first relates the good practices adopted in SSCM to the three aspects of sustainability and their interactions. The second organizes the management systems in layers according to how they address the sustainability aspects. SSCM, as well as Sustainable Operations Management, present themselves as the most comprehensive management model. In SSCM new practices are used together with those found in the supply chain management.
\end{abstract}

Keywords: good practices, sustainability, sustainable supply chain, management systems

\section{Introduction}

In a survey conducted by Economist Intelligence Unit (EIU) (2008) with over 1200 executives worldwide and sustainability experts, $53 \%$ of firms worldwide claim to have a coherent sustainability policy. However, only half of them extend this beyond internal operations to encompass their supply chains. Less than one in three executives (29\%) says their company has a coherent strategy that covers the whole business and its supply chain. Uncertainty also lingers as to whether sustainability can be seen as an opportunity, or if it is merely another drag on the bottom line.

Corporations have come under increasing pressure from the governments, NGOs and several stakeholders to address the economic, environmental, and social implications of their activities. As a part of their response to this pressure, many corporations are now considering supply chain issues to be a part of their overall sustainability program. (Frank, 2008; BSR, 2007; NZBCSD, 2003; Morali \& Searcy, 2010). The sustainable development challenges the corporations to operate in a transparent and accountable manner, in view of the existence of a well informed and active base of stakeholders (Hart \& Milstein, 2004).

The view that social responsibility is applicable to all organizations emerged as different types of organizations, not just those in the business world, recognized that they too had responsibilities for contributing to sustainable development (ISO/DIS 26000, 2009). The elements of social responsibility reflect the expectations of society at a particular time, and are therefore liable to change. As society's concerns change, its expectations of organizations also change to reflect those concerns. For a number of reasons, concern about the social responsibility of organizations is increasing. Globalization, greater ease of mobility and accessibility, and the availability of instant communications mean that individuals and organizations around the world are finding it easier to know about the activities of organizations in both nearby and distant locations. 
Unlike many people might believe, sustainability and supply chain share common aspects, like: risk management - damages caused by the products and its residues and work safety; transparence - company practices must be transparent to the stakeholders and strategy and organizational culture - the sustainable initiatives must be part of the company strategy and culture (Carter \& Rogers, 2008).

On the EIU survey (2008), the biggest top three benefits that businessmen expect to derive from adopting sustainable practices are ability to attract new customers/retain existing ones followed by improved shareholder value and increased profitability. However, driven by the stock market, corporations have tended to overemphasize short term gains by concentrating more on quarterly results than the foundation for long-term success. Such an obsession with short-term profits is contrary to the spirit of sustainability, which requires the firm to meet the needs of its stakeholders in the future as well as today (Dyllick \& Hockerts, 2002).

There is a continuing need to explore approaches to integrate all three dimensions of sustainability into supply chain management, namely the environmental, social and economic dimensions. Second, there is a need to develop management systems for sustainable supply chain management SSCM (Morali \& Searcy, 2010). For them, the future research must go beyond studying these two areas separately and that focus must move towards a more integrated approach.

Sustainable supply chain management SSCM has its roots in supply chain management and its concept can be extended by adding the aspect of sustainability. Sustainability refers to an integration of social, environmental, and economic issues (Carter \& Rogers, 2008). They define SSCM as the strategic achievement and integration of an organization's social, environmental, and economic goals through the systemic coordination of key inter-organizational business processes to improve the long-term economic performance of the individual company and its value network.

The problem statement is: which are the main management systems related to sustainable supply chain management and how their practices are related to the sustainability dimensions? The objective of this study is to identify these practices and systems related to SSCM. The remainder of the paper is organized into four main sections. In the next section, the literature review on management systems and sustainability practices is presented. Then, the methodology and data collection followed by descriptive analysis. This provides the context necessary for the fourth section, which presents the discussion of the results and the proposal of two frameworks. Finally, the paper finishes with a brief conclusion that summarizes the objective of this study.

\section{Literature Review}

Both sustainability management and supply chain management form the background against which this review was conducted. For the purposes of this paper, we consider the perspective that the triple bottom line is an important mean to measure the organization's progress toward the ultimate objective of being truly sustainable. A supply chain that performs well on traditional management systems and practices provides the foundation of a sustainable supply chain.

\subsection{The Management Systems on SSCM}

For Pagell and $\mathrm{Wu}$ (2009), a crucial theoretical discussion involves the ecocentric view that suggests that an organization should consider its relationships with the broader social and natural environments. A sustainable chain should consider a variety of stakeholders - community members, competitors, suppliers, employees and clients. However, only few management systems can fit in this situation. The way that companies will set up the sustainable supply chain management systems is directly related to how they respond to the pressure of the above stakeholders. These pressures are legal demands/regulation, customer demands, environmental and social pressure groups.

When the company is pressured, it usually passes this pressure along the supply chain. By using the Life Cycle Management LCM, the company is looking at the overall supply chain of the product. It quite often has to take a longer part of the supply chain into account than needed for pure economic reasons (Seuring \& Muler, 2008). For Linnanem, Boström and Miettinen (1995) LCM consists of three visions: management vision - integrate environmental issues in the decisions taken by the company; engineering vision - optimize the environmental impact caused by the product during its life cycle and leadership vision - creation of a new organizational culture. Another system is the N-order supply chain that consists into several consecutive supply chains where the main product commercialized can be reused.

A supply chain of first order indicates that its substantial part is based on products that are not reusable and materials that are non-recyclable. When this chain is extended to n-order (for instance, second order), it is based on reusable products and recyclable materials. After a reverse logistics, the product collected can be redistributed 
to another group of consumers as is the case of the following example (Svensson, 2007). This system is called N-order Supply Chain.

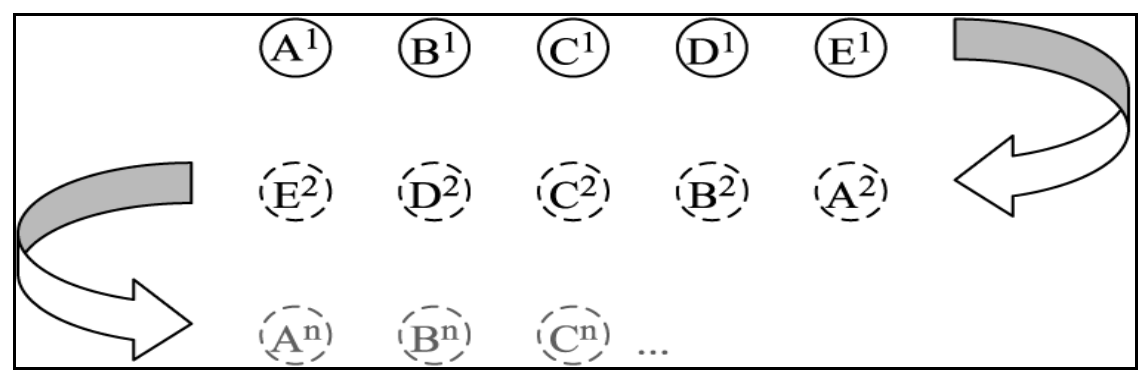

Figure 1. N-Order supply chain

In a clothing company, the origin point are the designers and the marketing departments of the department stores when the characteristics and specifications of the material are agreed. This corresponds to the origin point A1. The manufacturing location is the next point B1. It is then distributed to regional sellers, $\mathrm{C} 1$ and repacked in smaller volumes to retailers in the market, D1. The consumers buy the products and use, E1, being then considered the consumption point. A second hand market or donation of used clothing originates the second order chain. Ohlsson and Svensson (2003) state that the second hand market has raised considerably in Sweden and $3 / 4$ of the Sweden consumers donate used clothing to charity institutions.

A similar management system is Closed Loop Supply Chain CLSC. It includes the traditional supply chain activities and other additional ones like, product acquisition to collect from the users, reverse logistics, testing, classification and material disposition to determine the product conditions and choose the best economic option and remarketing to create and explore new markets for the "renewed" products (Guide, Harrison, \& Van Wassenhove, 2003).

A second set of management systems addresses the pressure of environmental groups. They are Green Supply Chain Management GSCM and Product Recovery Management PRM.

Bowen, Cousine, lamming and Faruk (2001) define GSCM as activities of supply chain management that are attempts to improve the environmental performance of the materials acquired and from the suppliers. It should expand the traditional concept of supply chain management by embracing the environmental issues in order to minimize these impacts throughout the product life cycle. They highlight two major aspects of the GSCM that are: 1) making the chain processes greener and 2) sourcing of greener products.

Most products are thrown away or incinerated with considerable damages to the environment. More severe legislation and greater awareness of the consumers are making the companies to rethink their responsibilities on their products after the use and disposal. PRM address this issue. Krikke (1998) establishes four levels of product recovery: product, module, parts and material. Recycling is the product recovery at the material level being the lowest level. Cannibalization is the product recovery at the parts level and remanufacturing is the recovery at the module level. The highest level is repair at the product level. We can notice that PRM is focused in the product recovery given the ecological and economic benefits.

The last two management systems discussed address the triple bottom line, ie, the three dimensions of sustainability. Integrated Chain Management ICM is the integrated management of a supply chain in the environmental, social and economic responsibility for production, consumption, distribution and disposal of a product (Wolters, James, \& Bouman, 1997; Cramer, 1996). Its main objective is to enhance the performance of the chain through the interaction of the members, better material flow and more efficient production. This will result in a cleaner and more responsible production that leads to positive impacts to the environment and society.

Similar to the above system is the Sustainable Operation Management SOM. This system integrates the profit and the efficiency of the traditional practices of the Operations Management with the social demands of the stakeholders and potential impacts in the environment (Kleindorfer, Singhal, \& Van Wassenhove, 2005). SOM is based on three areas: green products and processes, green and lean operations, remanufacturing and closed loop supply chain. 


\subsection{The Management Practices on SSCM}

Pagell and $\mathrm{Wu}$ (2009) used case studies of 10 exemplar firms to build a coherent and testable model of the management practices that supply chain managers will need to engage in to create a sustainable supply chain. They examined both the social and environmental outcomes of the chain's activities. They suggest that the practices that lead to a more sustainable supply chain are equal parts best practices in traditional supply chain management and new behaviors, some of which run counter to existing accepted best practices. Some of these practices are discussed below.

Ecodesign is an approach that consists in reducing the environmental impacts of a product while maintaining at same time its use quality - performance and functionality, in order to improve the life quality of today and tomorrow's users (Kazazian, 2005). It is a new way of conceiving a product and its environmental impact throughout the life cycle.

As an extension of this practice, we have the life cycle analysis LCA. It began around 70s and lead to the publication of the international standard ISO 14040 (Hunt \& Franklin, 1996). According to this norm, Life Cycle Analysis is a technique for assessing the environmental aspects and potential impacts associated with a product by:

- compiling an inventory of relevant inputs and outputs of a product system;

- evaluating the potential environmental impacts associated with those inputs and outputs;

- the interpretation of the results of phases of inventory analysis and impact assessment in relation to the objectives proposed. ISO 14040 specifies the general structure, principles and requirements to conduct and report studies of life cycle analysis.

However, these two practices will only be fully effective if the company is able to trace what happens to an item/product throughout the entire supply chain. ISO 8402 defines traceability as the ability to trace the history, the application or the location of an item through previously recorded information. This is an internal practice of sharing information among chain members about materials and methods to optimize noneconomic chain performance and minimize risks. Its activities include demanding information on all materials used in a supplier's product and/or requiring that suppliers provide evidence that working conditions are acceptable (Pagell \& Wu, 2009).

Sharing information among members of the supply chain is just one part of what Vieira (2006) calls collaborative logistics. For him, the chain members should interact with each other to add value in the development, manufacturing, commercialization and distribution of the products. Therefore, everything is designed and implemented in an integrated manner. For Carter and Rogers (2008), collaborative behaviors with suppliers and clients are essential competences in a sustainable environmental supply chain.

Regarding the relationship only with suppliers, another good practice is the green purchasing. Mulder (1998) defines green purchasing as the practice used by public authorities and private companies to consider the sourcing of green products and the performance of the sourcing process when buying products or services. Zsidisin and Hendrick (1998) identified the following critical factors for green purchasing: engage the suppliers in the product specification phase which considers the environmental requirements for the items acquired, the collaboration with the suppliers for the environmental objectives, auditing and supplier certification.

Looking back inside the organization, there are two practices - lean and international standards. Lean production has emerged as a manufacturing system with the objective to enhance the processes and procedures by continuous waste reduction, like, inventory excess between work stations and high waiting time (Bamber \& Dale, 2000; Hines \& Taylor, 2000). Pagell and Wu (2009) suggest that lean, JIT and other continuous improvement focused operational philosophies may be most useful for making an existing supply chain more sustainable. However, the same operational philosophy may become a hindrance when organization needs to radically change what they do to become truly sustainable.

The international standards such as ISO 14000, ISO 26000 and SA 8000 identified in the literature have strong roots in ISO 9000. These standards or practices are well known and cited in several papers related to the sustainable supply chain (Zsidisin \& Hendrick, 1998; Seuring \& Müller, 2008; Kleindorfer et al., 2005). These authors discuss the linkage between these norms and the environmental, social and quality dimensions.

The International Standard ISO 26000 is intended to promote common understanding in the field of social responsibility. It is intended to complement other instruments and initiatives for social responsibility, and not to replace them. On the other hand, the International Standard ISO 14000 allows an organization to develop and implement a policy and objectives that take into account the legal requirements and information related to the 
significant environmental aspects. These two standards can also be extended to the suppliers, where companies increasingly ask their suppliers to perform according to the guidelines set by the environmental and social standards (Seuring \& Muller, 2008).

Finally, the last practice discussed is reverse logistics. For Leite (2009), after sale reverse distribution channels consist of different forms and possibilities of products return, with little or no use, that flow in the reverse direction of the supply chain, from end consumer to retail or manufacturer and from retail to manufacturer. These channels are motivated by problems related to quality and/or to commercial processes between companies, making possible the return of the products to the business cycle. The members of these reverse channels are basically the same as of the direct channels. Leite (2003) also states that reverse logistics can generate economic, ecological, legal, logistic and corporate image benefits.

\section{Methodology and Data Collection}

This section presents the following parts: 1) criteria for selection of articles; 2) criteria for classification of articles.

\subsection{Criteria for Selection of Articles}

The search for related publications was mainly conducted using keywords search. These were initially sustainability, sustainable development, sustainable supply chain management and supply chain management. After a first quick content analysis, identified articles were in or excluded from the analysis. Since sustainable supply chain management is a young and developing field, and given its cross-functional nature, restricting our sample to those keywords was not deemed appropriate. We expanded our research for additional articles researching other keywords. These were corporate social responsibility, business sustainability, green supply chain, environmental management system and environmental performance. Major databases were used to search for related articles, such as those provided by library services-Ebsco, IEEE and Proquest, by major publishers Elsevier, Emerald and Wiley. Research on some brazilian journals was also conducted. This search returned with hundreds of articles but since we were interested on articles related to management systems and management practices applied on SSCM, we refined to 40 papers that were considered for our analysis.

\subsection{Criteria for Classification of Articles}

The articles were classified in the following categories:

- Quantity of articles by year of publication;

- Quantity of articles by journal;

- Quantity of articles by each dimension of sustainability — environmental, economic, social and their interfaces - environment/economic, environment/social, economic/social and environment/economic/social;

- Quantity of articles by year of publication and by each dimension of sustainability and their interfaces.

\subsubsection{Articles by Year of Publication}

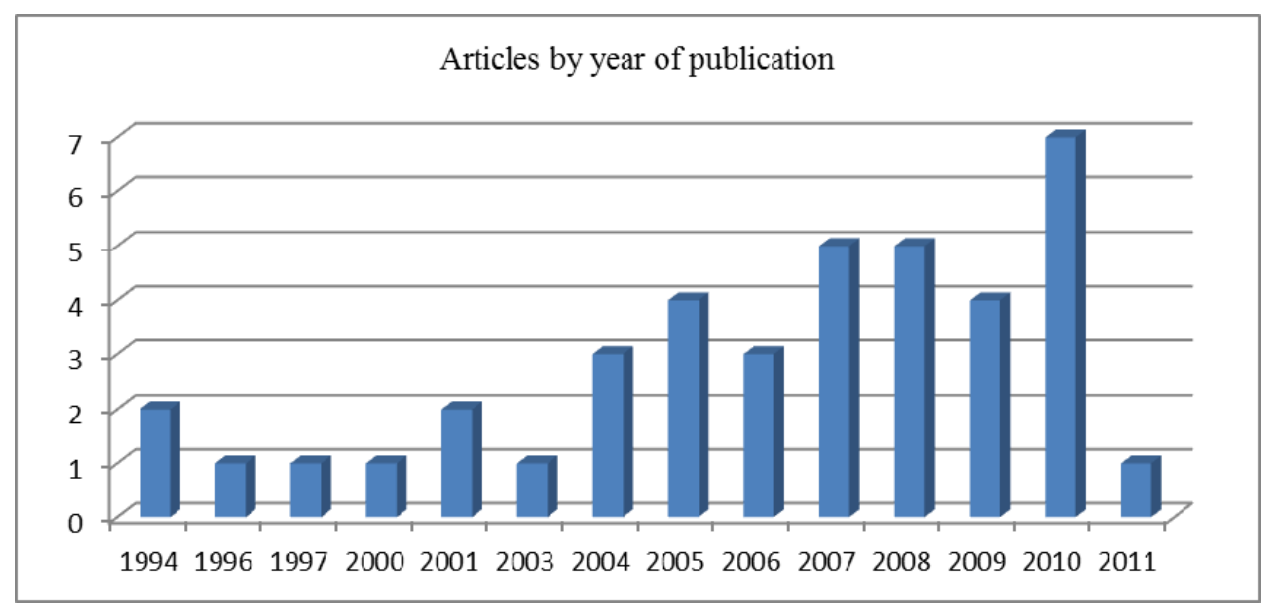

Figure 2. Articles by year of publication 
It is remarkable that the number of articles has grown considerably after 2004. This growth is due to the concern and interest that companies, executives, society and scholars have on sustainability. The reason why there is only one article in 2011 is that the search of articles was completed in the beginning of 2012. See figure 2.

\subsubsection{Articles by Main Journals}

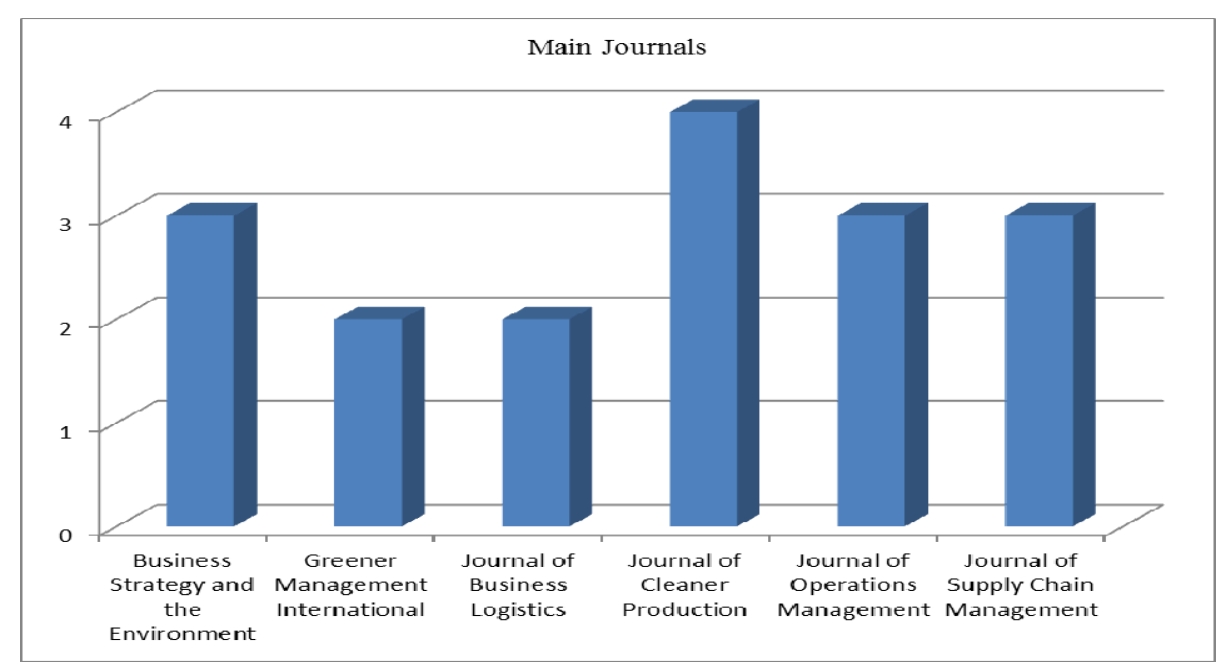

Figure 3. Articles by main journals

These 6 journals represent nearly $50 \%$ of the articles researched by the author. The other half is widespread over 25 different journals. The results show the diversity of journals represented and the breadth of interest and the potential for emerging alternative perspectives on sustainable supply chain. See figure 3 .

\subsubsection{Articles by Dimension of Sustainability}

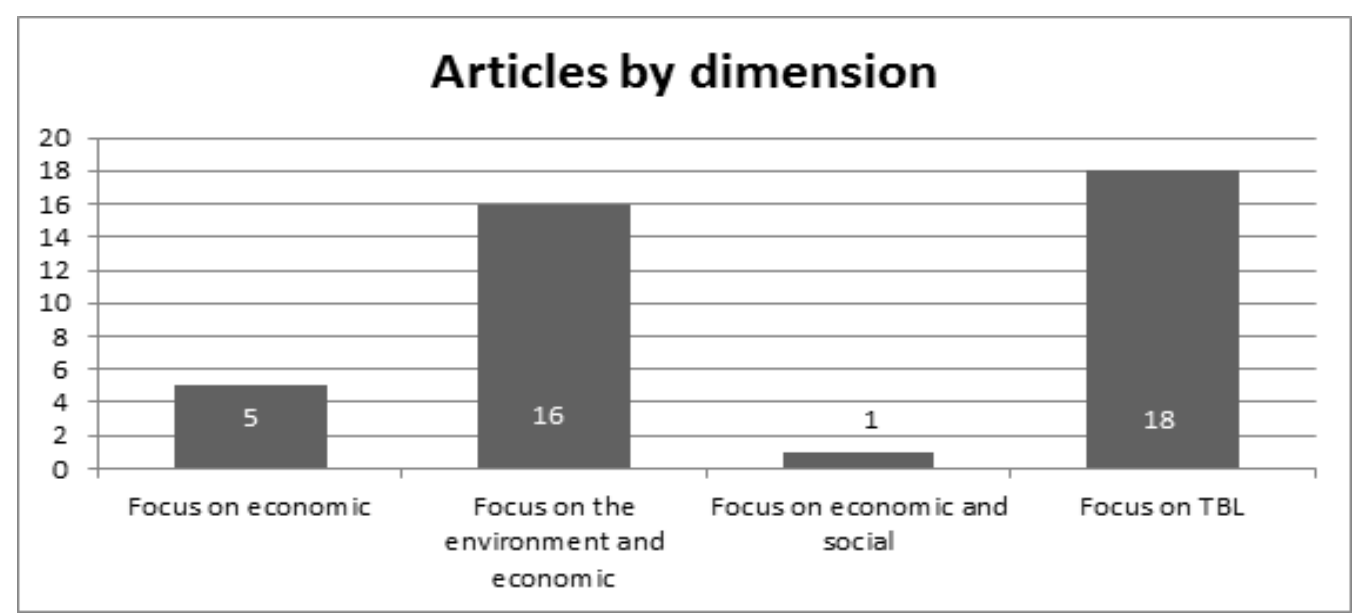

Figure 4. Articles by dimension of sustainability

Most of 40 articles researched (18) deals with the three dimensions of sustainability, so called, triple bottom line, being followed by articles that deal with the environmental and economic dimensions (16). This statistics goes in line what other authors highlighted, that the social dimension of the sustainability is poorly depicted (Seuring $\&$ Müller, 2008; Pagell \& Wu, 2009). See figure 4.

3.2.4 Articles by Year of Publication and by Dimension of Sustainability

These two figures (5 and 6) go in line with what was said before that is the growth of articles on 2004 onwards. 


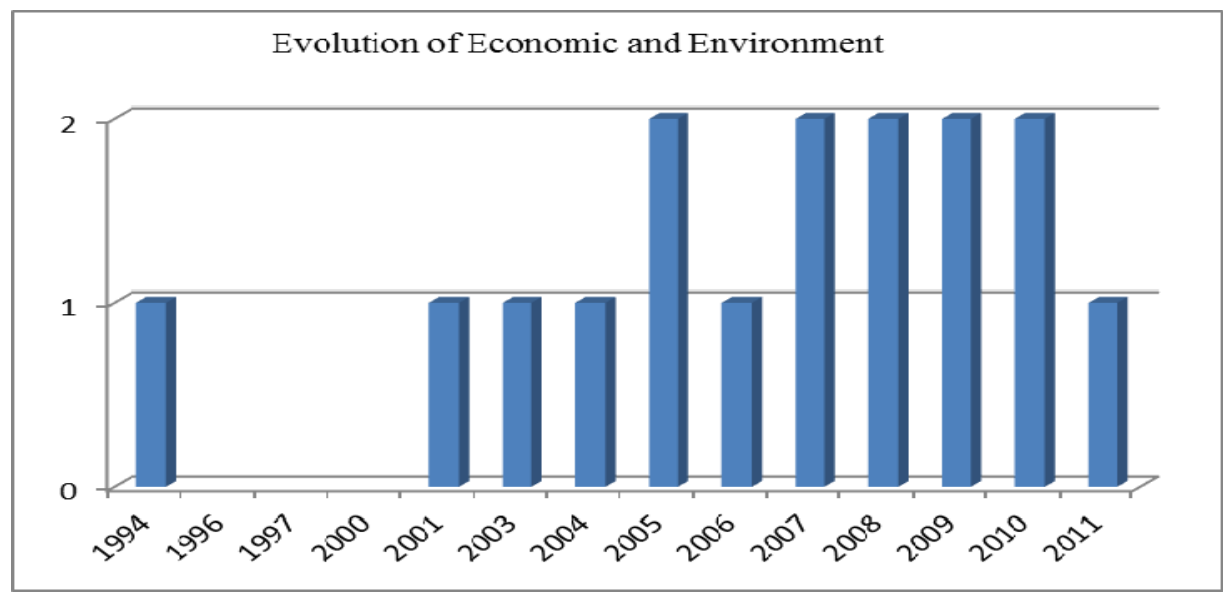

Figure 5. Evolution of economic and environment

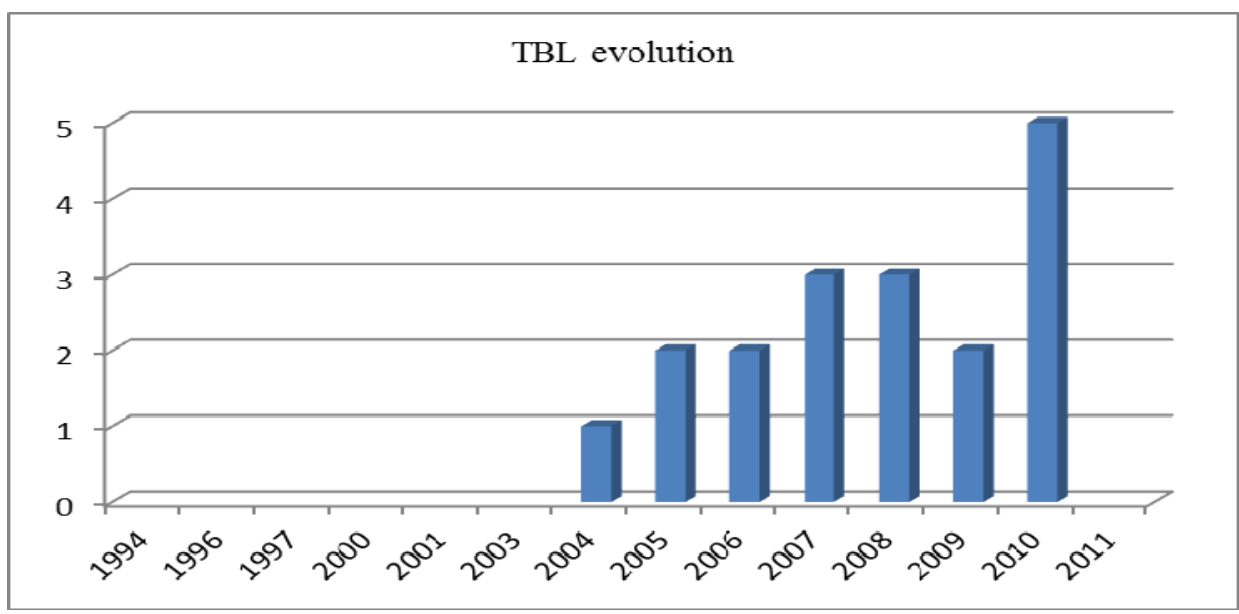

Figure 6. Evolution of TBL

\section{Discussion and Proposal of Two Frameworks}

\subsection{Management Systems}

According to Seuring and Muller (2008), the management systems play an important role in overcoming the barriers for implementing sustainable supply chains and can be related to the minimum performance required. They mainly center on environmental and economic approaches that will culminate in the development of the sustainable supply chain. A management system with focus on social aspects was not found in our research.

However, a number of companies has used supplier evaluation schemes which integrate environmental and social criteria. Related social topics include codes of conduct that condemn work discrimination, freedom of association, diversity, health and safety, child labor, fair treatment and working hours (NZBCSD, 2003).

Unlike the social dimension, we have found many papers whose management systems are focused on the environmental dimension and not so many papers on the economic dimension. They present, in general, several common characteristics and can be organized according to the level of complexity of their operational activities and integration with the dimensions of sustainability. The more complex and more integrated, the higher will be the management system in the hierarchy.

Product Recovery Management PRM, for instance, is an environment system of low complexity. It can defined as the management of all used and discarded products, components and materials in which a focal company is legally responsible, by contract or any other mean (Thierry, Salomon, Vans Nunen, \& Van Wassenhove, 1995). The closed loop supply chain management CLSCM can be considered a more complex system to manage a supply chain. It has a concern with the design, control and operation of the supply chain, besides the reverse logistics and product recovery, to add value throughout the entire life cycle (Guide \& Wassenhove, 2003). 
Side by side with CLSCM, we considered Product Life Cycle Management PLCM. This system is a total end-to-end life cycle approach to sustainability (Seuring, 2004). It is concerned with the company's total environmental impact - from design to raw material, to production, distribution, consumer use and disposal of the product by the consumer (Karna \& Heiskanen, 1998).

Upper in the hierarchy, we have considered Green Supply Chain Management GSCM since this system embraces the environmental and economic dimensions. Zsidisin and Siferd (2001) have used the term Environmental Supply Chain Management as synonymous of GSCM. They define as the set of actions taken in response to the concerns with environment in the aspects of design, acquisition, production, distribution, use, reuse and disposition of goods and services of the company.

Similar to what we have just done with the management systems of the environmental dimension, we now move to the economic dimension to discuss its related management systems. The traditional system of Supply Chain Management SCM was placed below the N-order Supply Chain Management. This innovative approach extends the conventional supply chain (first order) which ends in the final consumer. The second order starts where the first order ends. The product discharged by the final consumer is then collected and sent to another group of customers to be reused originating a new order of the supply chain (Svensson, 2007).

At the top of the hierarchy, we place Sustainable Supply Chain Management SSCM. This is the result of the merger of the environmental dimension (with Green Supply Chain Management) with the economic dimension (with N-order Supply Chain Management) and the addition of the social dimension (Social Responsibility). For Carter and Rogers (2008) this system is the strategic integration of the social, economic and environmental goals of a company. This is accomplished by the systemic coordination of the internal and the interorganizational business processes in order to improve company's long term economic performance and the value of the entire supply chain. Similarly, Pagel and Wu (2009) state that SSCM is the specific managerial actions that are taken to make the supply chain more sustainable with an end goal of creating a truly sustainable chain.

Another two management systems that are similar to SSCM are Sustainable Operations Management SOM and Integrated Chain Management ICM. They both work with the three sustainability dimensions, focus on the entire supply chain, have similar definitions and use similar practices. They are placed side by side with SSCM.

To sum up the above discussion, we present the following framework (figure 7) which highlights the links between the various management systems. As said before, these systems are placed according the level of complexity of their operational activities and integration with the dimensions of sustainability. Note that social aspect is the only part of sustainability that does not follow a natural integration and evolution among the others management systems.

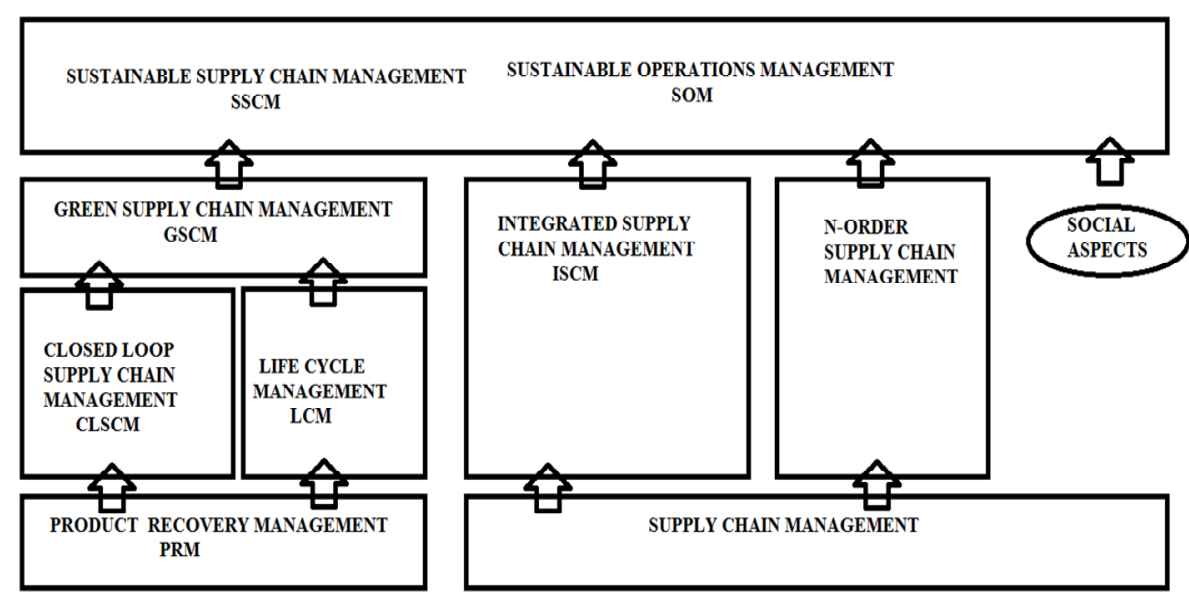

Figure 7. Links between the management systems

\subsection{Management Practices}

In this section, we discuss the practices and their relation to the sustainability dimensions. For Pagel and $\mathrm{Wu}$ (2009), although best practices can be seen as a foundation for sustainability, they state that no coherent set of practices in SSCM has yet emerged. 
Some authors have explored the linkage between existing practices in supply chain management (economic) and environmental practices, with almost no coverage of the social dimension. This seems to be the case of reverse logistics practice. It presents environmental and economic benefits. However, its social dimension was not found in our research.

Three other practices are related with economic and environmental dimensions. Eco Design presents ecological benefits since the company has to consider environmental concerns when designing the product. It also presents economic benefits because its design is meant for recovery and reuse of the components of value. It also seeks leaner production in regards of materials spent in the production.

Green Purchasing differentiates from traditional purchasing in the sense it introduces environmental concerns in the acquisition process of a product or a service. Collaborative behavior with suppliers is a component for creating an environmentally sustainable supply chain. The economic benefits are also present in this practice by seeking more efficient processes and economizing resources.

Lean practices and tools have long been linked to improved operational performance with the elimination of wastes and contributing to non-obsolescence of the product. They also improve environmental performance as well with the benefits of a cleaner production and less residues generation and disposition in the environment. However, in Pagell and Wu study (2009), the adoption of leans or similar principles is not a salient factor that explains the companies' achievement in sustainability.

The practice that links social and economic dimensions of the sustainability is traceability. Traceability presents economic benefits by reducing losses in the production and tracking problems in an efficient way, and social benefits, by forcing suppliers to provide better working conditions.

We have considered only two practices in SSCM that are able to link the three dimensions at same time. These are cooperation with suppliers and standardization.

Cooperation with suppliers increases in importance. For Seuring and Muller (2008), this does not extend to first-tier suppliers, who are often the focus of conventional supply chain management. For them, in supply chain management for sustainable products, ensuring the quality of the product and the performance of the operational process might be as much of an issue as building partnerships for new product introductions, so the complete supply chain from raw materials to final consumers has to be integrated. To meet the social dimension, another fundamental activity is the supplier certification where social issues such as child labor and unsafe working condition are addressed.

The standardizations - ISO 9000, 14000, 2600 and SA 8000 (Social Accountability) - are clearly related to the three dimensions of sustainability. They establish international standards and their practices, when used all together, address economic (quality assurance), environment and social related approaches.

Finally, the last practice deals only with the environmental aspect of the sustainability. Life cycle analysis captures the environmental impacts of the chain leaving apart the social and economics components. According to ISO 14040, it aims to minimize the environment impact over the useful life of the product and to be used when designing the product (Karna \& Heiskanen, 1998). In this aspect, it keeps a close relation with Eco Design practice.

To sum up the above discussion, we present the following framework (figure 8) which relates the practices to the dimensions of sustainability and their interfaces. 


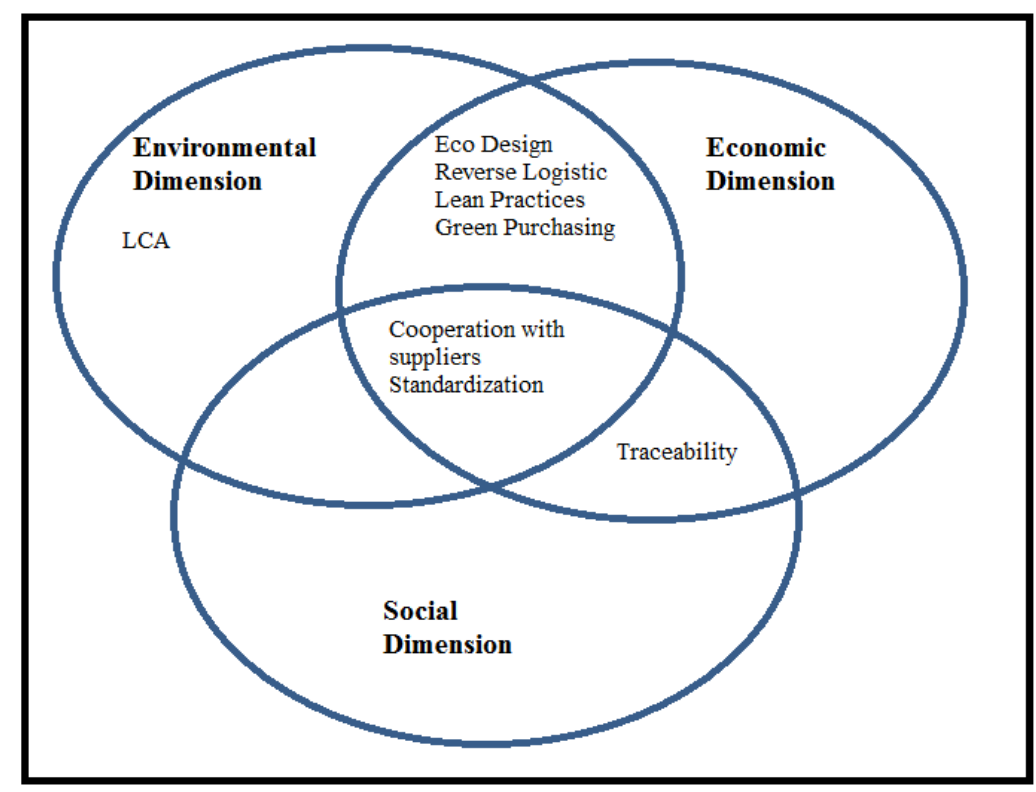

Figure 8. Relation of practices to the sustainability dimensions

\section{Conclusion}

Academic and corporate interest in sustainable supply chain management has grown considerably since mid of last decade. This is reflected in the number of papers published and in the variety of journals that publish this subject. The social dimension of the sustainability is rarely addressed in the literature, in contrast with papers that address the triple bottom line dimensions and economic/environmental dimensions. When looked by year of publication, the number of publications in the environment/economic interface has risen in 2004 onwards.

This study has taken a broad look at sustainable supply chain management and the management systems and practices emerging in this field. Sustainable chains are engaging in a wide set of managerial systems and practices that have been linked to enhance environmental and economic performance. Few of them, however, can be linked to address the three dimensions of sustainability. This is the case of SSCM, ICM and SOM, while four management systems embrace only the environmental dimension. On the practices side, only two address the three dimensions.

As said in the beginning of this paper, a supply chain that performs well on traditional management systems and practices provides the foundation of a sustainable supply chain.

In SSCM new practices are used together with those found in the supply chain management. The companies are also changing the way they relate with their suppliers and customers, establishing patterns and codes of conduct over the entire supply chain.

The authors propose two frameworks that summarize the objective of this study. One of them organizes the management systems in layers according to how they address the sustainability aspects. The other one relates the good practices adopted by the organizations to the three aspects of the sustainability and to their interactions. These two frameworks can be utilized by future researchers to consolidate the sustainable supply chain management concept.

Our study has its limitation which opens opportunities for future research. The management systems and practices discussed were only those identified in the literature ignoring those used in the organizations that might be novel or not yet identified in the literature. Future research needs to examine the systems and practices used in the organizations.

\section{References}

Bamber, L., \& Dale, B. G. (2000). Lean production: a study of application in a traditional manufacturing environment. Production Planning \& Control, 11(3). Retrieved December 15, 2012, from http://www.producaoonline.org.br/index.php/rpo/article/download/331/427 
Bowen, F. E., Cousine, P. D., lamming, R. C., \& Faruk, A. C. (2001). Explaining the gap between the theory and practice of green supply. Greener Management International, 35, 41-59.

BS Business for Social Responsibility. (2007). Perspectives on information management in sustainable supply chains. $\quad$ Retrieved January $15, \quad 2012, \quad$ from http://www.bsr.org/reports/BSR_Info-Management-Supply-Chains.pdf

Carter, C. R., \& Rogers, D. S. A. (2008). Framework of sustainable supply chain management: moving toward new theory. International Journal of Physical Distribution \& Logistic Management, 38(5), 360-387. http://dx.doi.org/10.1108/09600030810882816

Cramer, J. (1996). Experiences with implementing integrated chain management in Dutch Industry. Business $\begin{array}{llll}\text { Strategy and the } & \text { Environment, }\end{array}$ http://dx.doi.org/10.1002/(SICI)1099-0836(199603)5:1<38::AID-BSE36>3.0.CO;2-O

Dyllick, T., \& Hockerts, K. (2002). Beyond the business case for corporate sustainability. Business Strategy and the Environment, 11, 130-141. http://dx.doi.org/10.1002/bse.323

Economist Intelligence Unit (EIU). (2008). Doing good: Business and the sustainability challenge.

Frank, A. (2008). Sustainable Supply Chain Management: A tool for reinforcing shareholder value. Accenture, $1-12$.

Guide Jr., D. R., Harrison, T. P., \& Van Wassenhove, L. N. (2003). The Challenge of Closed-Loop Supply Chains. Interfaces 2003 Informs, 33(6), 3-6.

Guide, Jr. D. R., \& Van Wassenhove, L. H. (2003). Business Aspects of Closed-Loop Supply Chains. Pittsburgh, PA, USA: Carnegie Mellon University Press.

Hart, S., \& Milstein, M. B. (2004). Criando Valor Sustentável. RAE Executivo, 3(2).

Hines, P., \& Taylor, D. (2000). Going Lean. A guide to implementation. Lean Enterprise Research Center, Cardiff, UK.

Hunt, R. G., \& Franklin, W. E. (1996). LCA-How it came about-Personal reflection on the origin and the development of LCA in the USA. International Journal of Life Cycle Assessment, 4-7. http://dx.doi.org/10.1007/BF02978624

ISO/DIS 26000. (2009). Guidance on Social Responsibility. International Organization for Standardization.

Karna, A., \& Heishanen, E. (1998). The challenge of 'product chain' thinking for product development and design: the example of electrical and electronics products. Journal of Sustainable Product Design, 4(1), $26-36$.

Kazazian, T. (2005). Haverá a Idade das Coisas Leves-Design e Desenvolvimento Sustentável. São Paulo: Editora SENAC.

Kleindorfer, P. R., Singhal, K., \& Van Wassenhove, L. N. (2005). Sustainable Operations Management. $\begin{array}{llll}\text { Production } \quad \text { and } & \text { Management, } & \text { 48 }\end{array}$ http://dx.doi.org/10.1111/j.1937-5956.2005.tb00235.x

Krikke, H. R. (1998). Recovery strategies and reverse logistics network design. PhD thesis, University of Twente, Enschede, The Netherlands. Retrieved September, 2012, from http://arno.uvt.nl/show.cgi?fid $=113854$

Leite, P. R. (2003). Logística reversa: meio ambiente e competitividade. São Paulo Prentice Hall.

Leite, P. R. (2009). Pesquisa mostra evolução da Logística Reversa no país. Revista Tecnologística, XIV(162), $30-36$.

Linnanen, L., Boström, T., \& Miettinen, P. (1995). Life cycle management: integrated approach towards corporate environmental issues. Business Strategy and the Environment, 4, 117-127. http://dx.doi.org/10.1002/bse.3280040303

Morali, O., \& Searcy, C. (2010). Building Sustainability into Supply Chain Management: A Research Agenda. Proceedings of the First Annual Kent State International Symposium on Green Supply Chains. Canton, Ohio, July 29-30. Retrieved October 5, 2012, from http://www.kent.edu/business/greensupplychainsymposium/upload/Oguz-Morali-GSC2010.pdf

Mulder, L. (1998). Green Purchasing: Does It Make Sense. Electronics and the Environment. Proceedings of the 
1998 IEEE International Symposium, 123-128. Retrieved February 15, 2013, from http://ieeexplore.ieee.org/stamp/stamp.jsp?arnumber $=00675043$

NZBCSD New Zealand Business Council for Sustainable Development. (2003). Business Guides to a Sustainable Supply Chain. Retrieved January 15, 2012, from http://nzbcsd.org.nz/supplychain/SupplyChain.pdf

Ohlsson, L., \& Svensson, M. (2003). Myrornas kladexport forodande for Afrika. Dagens Nyheter, 20, 20-34.

Pagell, M., \& Wu, Z. (2009). Building a more complete theory of sustainable supply chain management using case studies of 10 exemplars. Journal of Supply Chain Management, 45(2), 37-56. http://dx.doi.org/10.1111/j.1745-493X.2009.03162.x

Seuring, S. (2004). Industrial ecology, life cycles, supply chains: differences and interrelations. Business Strategy and the Environment, 13, 306-319. http://dx.doi.org/10.1002/bse.418

Seuring, S., \& Müller, M. (2008). From a Literature Review to a Conceptual Framework for Sustainable Supply Chain Management. Journal of Cleaner Production, 16(15), 1699-1710. http://dx.doi.org/10.1016/j.jclepro.2008.04.020

Svensson, G. (2007). Aspects of sustainable supply chain management (SSCM): conceptual framework and empirical example. Supply Chain Management: An International Journal, 12(4), 262-266. http://dx.doi.org/10.1108/13598540710759781

Thierry, M., Salomon, M., Vans Nunen, J., \& Van Wassenhove, L. (1995). Strategic issues in product recovery management. California Management Review, 37(2), 114-135. http://dx.doi.org/10.2307/41165792

Vieira, J. G. V. (2006). Avaliação do estado de colaboração logística entre indústria de bens de consumo e redes de varejo supermercadista. Tese de doutorado. POLI/USP - Departamento de Engenharia de Produção.

Wolters, T., James, P., \& Bouman, M. (1997). Stepping Stones for Integrated Chain Management in the Firm. Business Strategy and the Environment, 6(3), 121-132. http://dx.doi.org/10.1002/(SICI)1099-0836(199707)6:3<121::AID-BSE107>3.0.CO;2-C

Zsidisin, G. A., \& Hendrick, T. E. (1998). Purchasing's involvement in environmental issues: a multi-country perspective. Industrial Management \& Data Systems, 313-332. http://dx.doi.org/10.1108/02635579810241773

Zsidisin, G. A., \& Siferd, S. P. (2001). Environmental purchasing - a framework for theory development. European Journal of Purchasing \& Supply Management, 7, 61-73. http://dx.doi.org/10.1016/S0969-7012(00)00007-1

\section{Copyrights}

Copyright for this article is retained by the author(s), with first publication rights granted to the journal.

This is an open-access article distributed under the terms and conditions of the Creative Commons Attribution license (http://creativecommons.org/licenses/by/3.0/). 